\title{
Maternity Plus Class Model in Improving Efforts of Planning of Labor and Preventing of Pregnancy Complications at Risk in Rural Communities
}

\author{
$1^{\text {st }}$ Arulita Ika Fibriana \\ Department of Public Health \\ Universitas Negeri Semarang \\ Semarang, Indonesia \\ arulita.ika.f@mail.unnes.ac.id
}

\author{
$2^{\text {nd }}$ Muhammad Azinar \\ Department of Public Health \\ Universitas Negeri Semarang \\ Semarang, Indonesia \\ azinar.ikm@mail.unnec.ac.id
}

\author{
$3^{\text {rd }}$ Anik Setyo Wahyuningsih \\ Department of Public Health \\ Universitas Negeri Semarang \\ Semarang, Indonesia
}

\begin{abstract}
The development of "Maternity Plus Class" become a model of innovation in revitalizing the role of maternity class programs for family education in planning of labor and preventing of pregnancy at risk complications (P4K). This research was conducted in 4 villages in Singorojo Kendal subdistrict. The design of this research is quasi experiment with nonequivalent control group design with pretest and posttest. Data analysis using mix method. The results showed that there was significant differences between $\mathrm{P} 4 \mathrm{~K}$ efforts before the implementation of maternity class model. While in the control group did not show any significant difference.
\end{abstract}

Keywords-maternity class, pregnancy, childbirth, complications

\section{INTRODUCTION}

Deaths during pregnancy until 42 days postpartum is still a national problem. The MDG targets in reducing maternal mortality to $102 / 100,000$ live births have not been achieved. Romero et al (2007), stated that developing countries have accounted for $99 \%$ of total maternal deaths.

Kendal district is one of the areas that experienced problems of maternal mortality to date. In the last 3 years, there has been a significant increase in cases. In 2015 there were 23 cases, in 2016 occurred 19 cases, and increased significantly in 2017 that were 25 cases. This fact put Kendal as the eighth largest number of Maternal Mortality Rate in Central Java. Causes of maternal death cases are bleeding, hypertension and anemia $(\mathrm{Hb}<10 \mathrm{~g} / \mathrm{dl})$.

Research by Aeni mentioned the factors that affecting maternal mortality are pregnancy complication, labor complication, and history of maternal disease $[1,2]$. The history of the disease affect to the maternal death. The history of maternal disease can increase the maternal mortality.

These factors become risk factors for pregnancy. Pregnant women with those conditions categorized as pregnancy at high risk. Increased in maternal mortality was the impact of high number of pregnancy at high risk.
One of the areas in Kendal district which until now in pregnancy prone category is Public Health Center (Puskesmas) of Singorojo area. In the last 3 years, pregnancy at high risk cases in Public Health Center (Puskesmas) of Singorojo have increased. In 2015, it estimated $34.48 \%$ of cases of pregnancy at high risk, in 2016 increased to $56.30 \%$, and in 2017 reached to $55.28 \%$ (Public Health Center (Puskesmas) Singorojo, 2018).

These facts showed that more than half of the pregnancy occurs in these areas is pregnancies at high risk. This condition will have serious impact on the pregnant women such as abortion, bleeding, pregnancy poisoning, convulsions, reduced fetus movement, premature labor, developmental and growth disorders of pregnancy, early rupture of amnion membranes and complications during labor, even the most severe impact which is maternal death.

The geographical condition of the Singorojo sub-district which far from the refferal health care center of pregnancy with complications is the cause of the increase in maternal mortality, especially during labor. People in the Singorojo subdistrict must travel 33 kilometers to refer the pregnancy at risk and complicated labor cases (complications with obstetrics) to the hospital. This fact has an impact on the delay in reaching the birthplace, and the delay in obtaining emergency assistance experienced by pregnant women at high risk.

There are still pregnant women in the "4 too" category that are too old during labor, too young, too many children and also too close in range from previous pregnancy in Singorojo area is also the cause of pregnancy at high risk. Within the last year, in the area of Public Health Center (Puskesmas) of Singorojo are still found 92 cases of early labor (under the age of 18 years). This condition is very risky for the occurrence of labor complications and is not a few which cause maternal mortality, because at that age, anatomically and physiologically, the reproductive organs of the maternal are not perfectly prepared for pregnancy or labor. 
Labor planning in pregnant women at high risk is very necessary to be done as an effort to prevent complications and emergency labor. Labor planning is an activity that should be done by pregnant women and their families to plan for safe labor and all forms of preparation for labor. A pregnancy complication is an obstetric emergency that can cause death in both mother and baby. The inhibiting factors must be identified and minimized in order to resolve the problem. Otherwise, the factors that support, strengthen and all potential must be a power in solving the problem.

Previous study by researchers, is known that $72 \%$ of pregnant women did not know the exact steps in planning a safe labor. In addition, they also have not made any preparations for the labor. Pregnancy and labor are still regarded as natural processes experienced by a woman.

Education about planning of labor and preventing of pregnancy complications at risk is essential to be implemented in rural communities. All this time, education only done by midwives when providing Antenatal Care services. Community empowerment, especially pregnant women and their families is very important to be intensified, one of its strategy is to develop "Maternity Plus Class". This model is not only involves pregnant women, but also involves the husband and their family to become participants of the maternity class. In addition, this model uses the innovations of methods and media that are more attractive to the pregnant women and husband or their families.

Maternity class is a media of learning together directly face to face in the group about health for pregnant women. Expected goals after the pregnant women followed the maternity class are to improve knowledge, change attitudes and behavior of pregnant women to understand about pregnancy, pregnancy care, labor, postnatal care, family planning, newborn care, myths, infectious diseases and childbirth certificates.

This study aims to analyze the effect of the application of "Maternity Plus Class" model to the improvement of knowledge, attitude and effort of planning of labor and preventing of pregnancy complications at risk in rural area.

\section{MATERIALS AND METHODS}

\section{A. Research Design and Research Subjects}

The research design used was quasi experiment with nonequivalent control group design with pretest and posttest. In this design, there were two subject groups where one gets treated and one group as a control group. Both groups were given pre test and post test.

Research subjects in both groups were firstly given pretest. After that, each group run the program for 3 months (in cohort), then conducted a final test (post test) to find out how much influence the application of model "Maternity Plus Class" to the increased of knowledge, attitude and effort of planning of labor and prevention of complications pregnancy at risk in pregnant women in rural area.

The population of this study were pregnant women in 4 villages located in the Singorojo subdistrict in Kendal which had the highest number of pregnancy at high risk cases. Samples were determined purposively with the following conditions: the gestational age of the study subjects at the start of the study was 4 to 12 weeks (Trimester I), domiciled in the study area, and could read and write. Based on these conditions obtained the sample of 133 pregnant women. The sample is then divided into 2 groups namely the experimental group and the control group.

\section{B. Instruments and Data Collection Techniques}

The instrument used in this study was a questionnaire to collect data on knowledge, attitudes of pregnant women and their families and observation sheets, and documentation studies related to crosscheck of the effort of childbirth planning and prevention pregnancy at risk complications conducted by pregnant women in rural communities.

\section{Ethical Considerations}

This research has fulfilled the ethical feasibility by Health Research Ethics Committee of Universitas Negeri Semarang.

\section{Data Analysis}

The research data were analyzed to determine the effect of the application of the "Maternity Plus Class" model to the increased of knowledge, attitudes and efforts of planning of labor and prevention of pregnancy at risk complications for pregnant women in rural areas by $\mathrm{Mc}$ Nemar test or alternately.

\section{RESULTS AND DISCUSSION}

The Table (1) shows that the determinants of pregnancy at risk include: age factor, number of parity, range to previous pregnancy, history of miscarriage, history of caesar surgery and history of ecslampsia / pre ecslampsia. The study data showed $44.44 \%$ were pregnant at less than 20 years old and over 35 years old, $25 \%$ of mothers had a history of pregnancy of more than 4 times, $8.33 \%$ had a gestational range less than 2 years from the previous pregnancy, $5.92 \%$ had miscarriage and $16 \%$ of pregnant women had caesar surgery.

The Table (2) shows that after the implementation of the Model of Maternity Plus Class for three months, there was significant increase in knowledge related to pregnancy at risk, and planning of labor and prevention of complications ( $\mathrm{P} 4 \mathrm{~K}$ ) program. Before joined the Maternity Plus Class program, 46 pregnant women $(66.67 \%)$ still had poor knowledge about pregnancies at high risk and did not know the planning of labor and prevention of complications $(\mathrm{P} 4 \mathrm{~K})$ program completely. There were still many who do not know the risk factors for pregnancy at high risk that can be seen from too young or old pregnancies, previous pregnancy history such as miscarriage, 
caesarean birth, breech fetal location, the range of pregnancy is too close, and the history of disease suffered.

This fact changed significantly after joining the Maternity Plus Class program, the number of pregnant women whose knowledge is still in the less category reduced to 19 people $(27.53 \%)$. This shows that there was significant increase of knowledge between before and after the program of Maternity Plus Class ( $\mathrm{p}$ value 0,00001).

TABLE I. CHARACTERISTICS OF RESEARCH SAMPLES AND DETERMINANT OF PREGNANCY AT RISK

\begin{tabular}{|c|c|c|}
\hline Characteristic & $\mathrm{f}$ & $\%$ \\
\hline \multicolumn{3}{|l|}{ Age } \\
\hline$<20$ years & 18 & 13,33 \\
\hline 20-35 years & 75 & 55,56 \\
\hline$>35$ years & 42 & 31,11 \\
\hline \multicolumn{3}{|l|}{ Educational Level } \\
\hline Ungraduate from primary school & 3 & 2,22 \\
\hline Primary School/ equivalent & 9 & 6,67 \\
\hline Middle School/ equivalent & 81 & 59,68 \\
\hline High School/ equivalent & 34 & 25,18 \\
\hline Higher Education & 8 & 6,25 \\
\hline \multicolumn{3}{|l|}{ Occupational Status } \\
\hline Working & 65 & 48,00 \\
\hline Not working (Housewife) & 70 & 52,00 \\
\hline \multicolumn{3}{|l|}{ Height } \\
\hline$\leq 145 \mathrm{~cm}$ & 0 & 0,00 \\
\hline$>145 \mathrm{~cm}$ & 135 & 100,00 \\
\hline \multicolumn{3}{|l|}{ Amount of Parity } \\
\hline$<4$ times & 101 & 75,0 \\
\hline$\geq 4$ times & 34 & 25,0 \\
\hline \multicolumn{3}{|l|}{ Range with Previous Pregnancy } \\
\hline$<2$ years & 11 & 8,33 \\
\hline$\geq 2$ years & 124 & 91,67 \\
\hline \multicolumn{3}{|l|}{ Miscarriage } \\
\hline Ever & 8 & 5,92 \\
\hline Never & 127 & 94,08 \\
\hline \multicolumn{3}{|l|}{ Caesar Surgery } \\
\hline Ever & 22 & 16,00 \\
\hline Never & 113 & 84,00 \\
\hline \multicolumn{3}{|l|}{ History Eclampsia / Pre ecslampsia } \\
\hline Ever & 0 & 0,00 \\
\hline Never & 135 & 100,00 \\
\hline
\end{tabular}

The model of Maternity Plus Class was also significantly able to change pregnant women's attitudes toward planning of labor and prevention of complications $(\mathrm{P} 4 \mathrm{~K})$ program. It was indicated by $\mathrm{p}$ value 0,00001$)$. Before joined the Maternity Plus Class program, 37 pregnant women (53.62\%) still had an unfavorable attitude related to P4K efforts. They still thought that pregnancy is a natural process faced by every woman of childbearing age, so there is no need for intensive efforts in the planning of labor and prevention of complications $(\mathrm{P} 4 \mathrm{~K})$.

In addition, this model also has significantly improved P4K efforts. This is indicated before the program of Maternity Plus Class, 33 pregnant women have not implemented the $\mathrm{P} 4 \mathrm{~K}$ program completely. This is indicated by the evidence of many pregnant women who do not know their blood type, not prepare and raise health funds.

TABLE II. INFLUENCE OF IMPLEMENTATION OF MATERNITY PLUS CLASS MODEL ON INCREASING KNOWLEDGE, ATTITUDES AND EFFORTS OF PLANNING OF LABOR AND PREVENTION OF PREGNANCY AT RISK COMPLICATIONS

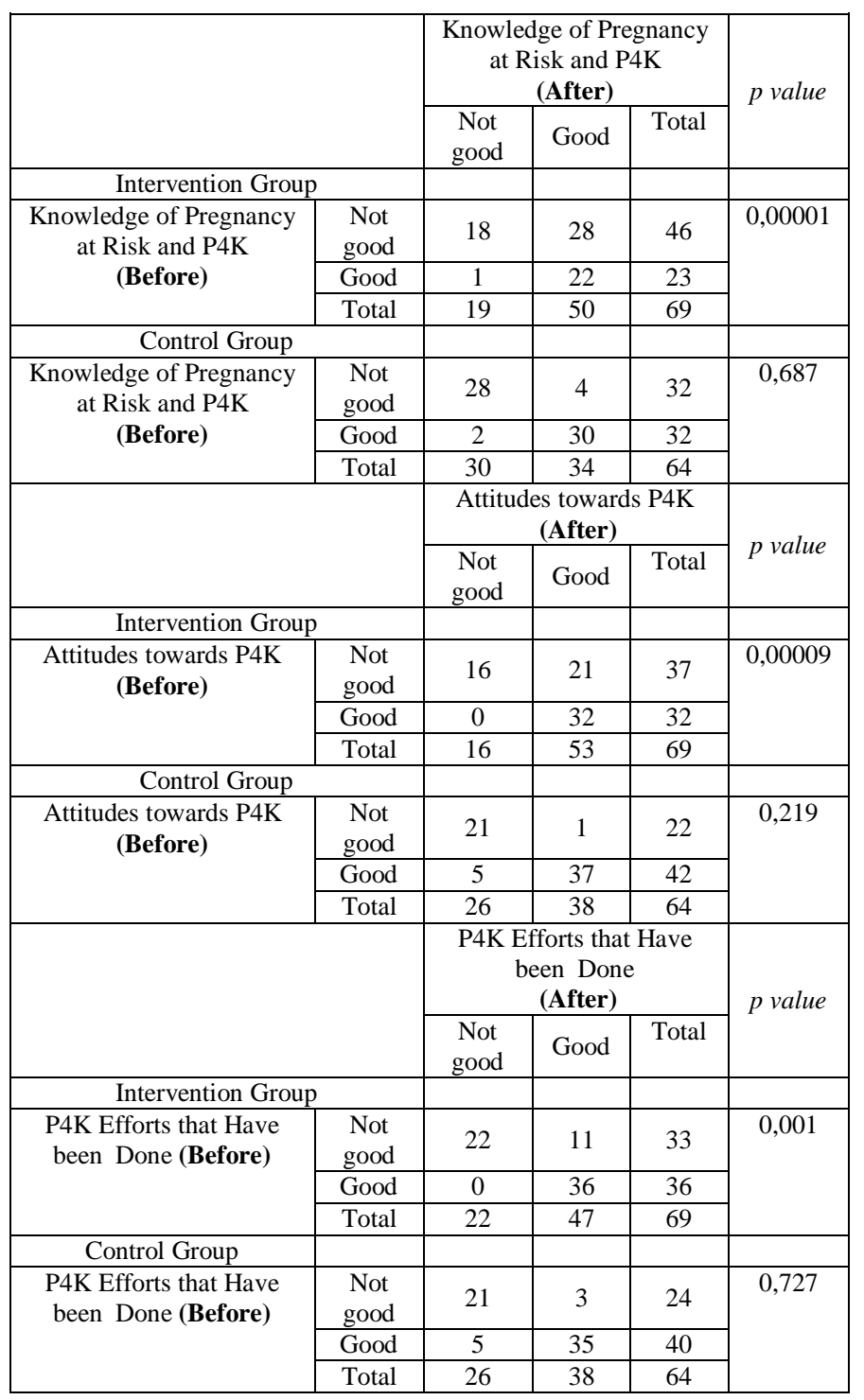


Other facts occurred in the control group, the group in which the Maternity Plus Class is run by the current mechanism applied in those areas, the knowledge, attitudes and efforts of $\mathrm{P} 4 \mathrm{~K}$ have not shown any significant change or improvement.

After joining the maternity class, pregnant women and their families could make behavioral changes and more aware of the importance of pregnancy examination to health services. So that the output achieved in the form of ANC visit, and pregnant women will later apply Program of planning of labor and prevention of complications (P4K) well. Research by Azeem, stated that there is a significant increase in knowledge on pregnant women who take the maternity class intensively [3].

Azwar's other research, attitude formation can occur because of education / training beside the personal experience, influence, culture, mass media, and emotional person [4]. Furthermore, maternal knowledge is very important to always be improved through the maternity class model to reduce risk factors for maternal death and perinatal death. Maternal knowledge is also associated with perinatal mortality (Ummul Mahmudah, et al, 2011).

Maternity class affect maternal knowledge and attitude (Elsa Budi Sihsilya R, et al, 2016). Maternity class can change the attitude of the community in the selection of labor assisted by medical personnel. The change of attitude in the selection of labor is encouraged by the better knowledge and motivation also the role of the good health personnes (Rochayah, 2012).

Models of Maternity Plus Class could also improve the ability of pregnant women and their husbands or families in the identification of pregnancies at risk and practices in risk prevention and possible pregnancy complications. This proved that the other outputs that are the strength of the Maternity Class program are the maternity class implemented: 1) the knowledge of maternity class participants is increased, 2) the better attitudes of pregnant women, 3) the better practice of risk prevention and maternal complications pregnancy, 4) Maternity class participants become more intensive to visit Antenatal Care (Fibriana and Azinar, 2016).

\section{CONCLUSIONS}

The results showed there were significant differences between effort planning of labor and prevention of complications in experiment group (p value 0,00002). Maternal knowledge and attitudes toward pregnancy at risk influenced antenatal care practice ( $p$ value 0,006 ). The level of pregnancy at risk affected behavior in planning of labor and prevention of complications ( $p$ value 0,00001). While in the control group did not show any significant difference.

\section{ACKNOWLEDGMENT}

Acknowledgments are submitted to the Directorate of Research and Community Service of the Directorate General for Research and Development of the Ministry of Research, Technology and Higher Education for the funding of the implementation of National Strategic Research.

\section{REFERENCES}

[1] N. Aeni, "Perilaku kesehatan ibu hamil di kabupaten Pati (Studi Pada Kasus Kematian Maternal Tahun 2011)." in Jurnal Litbang. 8 (3): 2007), 2012.

[2] N. Aeni, "Risk factors of maternal mortality," in Kesmas (Jurnal Kesehatan Masyarakat Nasional), 7(10) : 453-459, 2013.

[3] Azeem, "Hubungan pengetahuan dan sikap ibu hamil terhadap keikutsertaan kelas ibu di Public Health Center (Puskesmas) Metro Kecamatan Metro.” (4) 2: 224 - 232, 2011.

[4] Azwar, "Perbedaan efektifitas metode demonstrasi dengan pemutaran video tentang pemberantasan dbd terhadap peningkatan pengetahuan dan sikap anak sd di kecamatan wedarijaksa Kabupaten Pati." in Jurnal Promosi Kesehatan Indonesia. (2) 2: 115-129, 2008.

[5] T. Bazaar A, A. Azhari, "Maternal mortality and contributing risk factors." in Indonesian Journal of Obstetric and Gynecology. 36 (1): 813.

[6] Public Health Office of Kendal, "Laporan Data Kematian Ibu Tahun 2015." Kendal: Public Health Office of Kendal, in press.

[7] R. Gutierrez, V. Gustavo, E. de Lean P, Vargas LF, "Risk factors of maternal death in Mexico." in Birth. Vol $34: 21-25,2007$.

[8] C. Kaddour, R. Souissi, Z. Haddad, Zaghdoudi, M. Magouri, M. Saussi, et al., "Causes and risk factors of maternal mortality in the icu," in Critical Care, Volume 12 suppl 2 pp. 492, 2008.

[9] Karlsen et.al., "The relationship between maternal education and mortality among women giving birth in health care instituttions: analysis of the cross sectional who global survey on maternal and perinatal health," in BMC Public Health.Vol 11, 2011.

[10] Manuaba, I. A. Chandranita, "Gadar obstetri \& ginekologi \& obstetri ginekologi sosial untuk profesi bidan," in EGC. Jakarta, 2009.

[11] D. Pratitis, Kamidah, "Hubungan antara pengetahuan ibu hamil tentang tanda bahaya kehamilan dengan kepatuhan pemeriksaan kehamilan di BPS Ernawati Boyolali," in GASTER. (10) 2: 33-41, 2013.

[12] Romero-Gutiérrez G, Espitia-Vera A, Ponce-Ponce de León AL, HuertaVargas LF. Risk Factors of Maternal Death in Mexico. Birth. 2007 Mar;34(1):21-5

[13] WHO, "Trends in maternal mortality: 1990 to 2013," Estimates by WHO, UNICEF, 2013. 